\title{
Twostriped Walkingstick, Anisomorpha buprestoides (Stoll) (Insecta: Phasmatodea: Pseudophasmatidae) ${ }^{1}$
}

Michael C. Thomas ${ }^{2}$

\section{Introduction}

The most common stick insect in Florida is Anisomorpha buprestoides (Stoll), the so-called twostriped walkingstick. Other names applied to it and to stick insects in general include devil's riding horse, prairie alligator, stick bug, witch's horse, devil's darning needle, scorpion, and musk mare (Caudell 1903). The last common name is particularly apt as this species is capable of squirting a strong-smelling defensive spray that is painfully irritating to the eyes and mucous membranes (Gray 1835, Meinwald et al. 1962, Eisner 1965, Stewart 1937, Hatch et al. 1993, Paysse et al. 2001, Dziezyc 1992). Several recent inquiries about such incidents prompted the preparation of this circular.

\section{Distribution}

Anisomorpha buprestoides apparently occurs throughout Florida and around the Gulf Coastal Plain west to Texas. Rehn and Hebard (1916) listed specimens from South Carolina, Georgia, Alabama, and Florida. Blatchley (1920) added Mississippi and recorded it from "Gainesville, Sanford, Dunedin,
Cape Sable and Key West" in Florida. Specimens in the Florida State Collection of Arthropods (FSCA) are from the following Florida counties: Alachua, Brevard, Broward, Collier, Columbia, Dixie, Escambia, Gadsden, Gulf, Highlands, Lake, Leon, Levy, Liberty, Marion, Miami-Dade, Monroe, Nassau, Orange, Osceola, Putnam, Santa Rosa, St. Johns. The southernmost locality represented is Boca Chica Key in Monroe County. Specimens in the FSCA from outside Florida represent the following localities: Biloxi, MS; Jackson County, MS; Macon, GA; Atlanta, GA; Hanahan, SC; Terrebonne Parish, LA.

\section{Caudell (1903) stated that Anisomorpha} ferruginea occurs from Florida north to Pennsylvania; however, Rehn and Hebard (1916), noting the difficulty in distinguishing immature specimens of the two species, said the Florida record was based on a misidentified specimen of $A$. buprestoides and that the Pennsylvania record was based on mistranscribed label data. They (Rehn and Hebard 1916) gave the distribution of $A$. ferruginea as "...from just north of the Ohio River south over the Mississippi Valley to the Gulf States, west to extreme southeastern

1. This document is EENY-314 (originally published as DPI Entomology Circular No. 408), one of a series of Featured Creatures from the Entomology and Nematology Department, Florida Cooperative Extension Service, Institute of Food and Agricultural Sciences, University of Florida. Published: November 2003. This document is also available on Featured Creatures Website at http://creatures.ifas.ufl.edu. Please visit the EDIS Website at http://edis.ifas.ufl.edu. Additional information on these organisms, including many color photographs, is available at the Entomology and Nematology Department website at http://entnemdept.ifas.ufl.edu/.

2. Michael C. Thomas, Florida Department of Agriculture and Consumer Services, Division of Plant Industry, Gainesville, FL.

The Institute of Food and Agricultural Sciences (IFAS) is an Equal Employment Opportunity - Affirmative Action Employer authorized to provide research, educational information and other services only to individuals and institutions that function without regard to race, creed, color, religion, age, disability, sex, sexual orientation, marital status, national origin, political opinions or affiliations. For information on obtaining other extension publications, contact your county Cooperative Extension Service office. Florida Cooperative Extension Service / Institute of Food and Agricultural Sciences / University of Florida / Larry R. Arrington, Interim Dean 
Nebraska and eastward through the Appalachians in Virginia and in the high portions of the Carolinas and Georgia." Blatchley (1920) specifically listed it from Indiana, Illinois, and Louisiana.

\section{Identification}

The genus Anisomorpha Gray is the only Nearctic representative of the family Pseudophasmatidae (Bradley and Galil 1977). In the Nearctic, individuals of Anisomorpha are recognizable by the following combination of characters (Bradley and Galil 1977): middle and hind tibiae with sunken areolae on underside of apices; tarsi 5-segmented; first abdominal segment as long or longer than metanotum and fused with it; antennae long in both sexes; body without leaf-like lateral extensions; claws not finely pectinate; apterous; abdominal segments of male quadrate, of female transverse. Littig (1942) published a detailed study of the external morphology of A. buprestoides.

Anisomorpha buprestoides is a large, stout (for a stick insect) brown phasmid with three conspicuous longitudinal black stripes. Females average $67.7 \mathrm{~mm}$ in length; males are smaller and more slender, averaging $41.7 \mathrm{~mm}$ (Littig 1942). There is a strikingly distinct black and white color form that is found only in the Ocala National Forest scrub (Hetrick 1949a), the taxonomic status of which should be investigated. Both forms suffer considerable discoloration upon death and pinned specimens are not nearly as distinctively marked as living individuals. A second species, A. ferruginea (Palisot de Beauvois), occurs in the southeastern U.S., but apparently does not occur in Florida. It is distinguished by its smaller size, paler color and lack of conspicuous striping. There are no specimens of this species in the Florida State Collection of Arthropods. Both species are commonly found with the small males riding atop the larger females.

\section{Habits and Habitats}

\section{Like all stick insects, $A$. buprestoides is} herbivorus, feeding on the leaves of trees and shrubs. Gunning (1987) reported females feeding on crepe myrtle (Lagerstroemia indica L.) and roses in Louisiana; neither coupled nor free-roaming males were observed to feed. Hetrick (1949a) observed individuals of the Ocala National Forest form feeding primarily on oak (Quercus spp.), but also on rosemary (Ceratiola ericoides Michx.) and lyonia (Lyonia ferruginea Nutt.); although individuals often were found on scrub palmetto (Sabal etonia Swingle) they were not observed to feed on it. Meinwald et al. (1962) successfully maintained a laboratory colony of this species on privet (Ligustrum sp.). This stick insect sometimes is quite abundant; Hetrick (1949a) reported examining "several thousand" mating pairs of the Ocala National Forest color form. However, I know of no reports of this species causing serious defoliation as has been reported for some other stick insects (e.g., Blatchley 1920). It often forms aggregations of many individuals under loose bark or in other sheltered places (Gunning 1987, Davis 1914, Blatchley 1920).

Stick insects in general are reported to simply drop eggs from their feeding perches onto the ground. However, the female of $A$. buprestoides apparently secretes her eggs on the ground. Hetrick (1949a, 1949b) observed many females of the Ocala National Forest form dig small pits in the sandy soil, deposit eight to 10 eggs in the pit, and cover them over with sand before moving on to a new oviposition site. Gunning (1987) observed two females ovipositing into crevices of pine bark used as mulch in a garden in Louisiana; his observations suggest the period of activity of this species is primarily nocturnal.

The life history of this species has not been reported in detail, but it is evident from reports and specimen data that in Florida adults are most abundant in the fall, at which time oviposition takes place.

\section{Defensive Secretion}

The ability of this species to defend itself with a particularly odiferous secretion was reported as early as 1835 , when Gray in describing the genus quoted an account by Thomas Say "...that when taken they discharged a milky fluid from two pores of the thorax, diffusing a strong odor..." Albert (1947) also described it as a "...rather thick, tenacious white material..." Blatchley (1920) described it as having "...a peculiar, though somewhat pleasing odor, which has been likened to that of the common everlasting, 


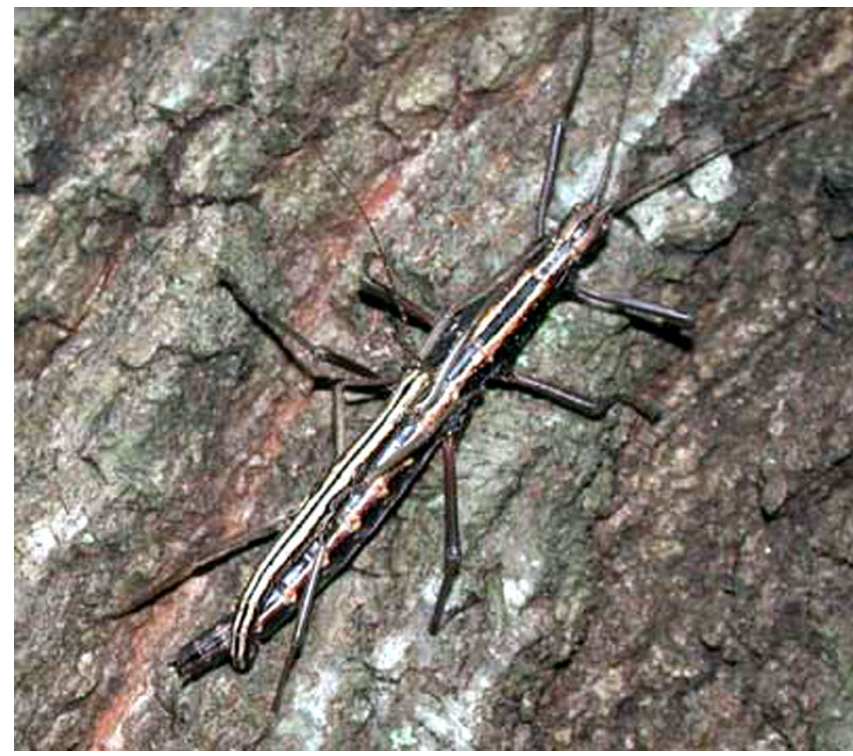

Figure 1. Male and female of the twostriped walkingstick, Anisomorpha buprestoides (Stoll), as usually seen. The female is the larger of the two. Credits: Photograph by: Michael Thomas, FDOACS-DPI

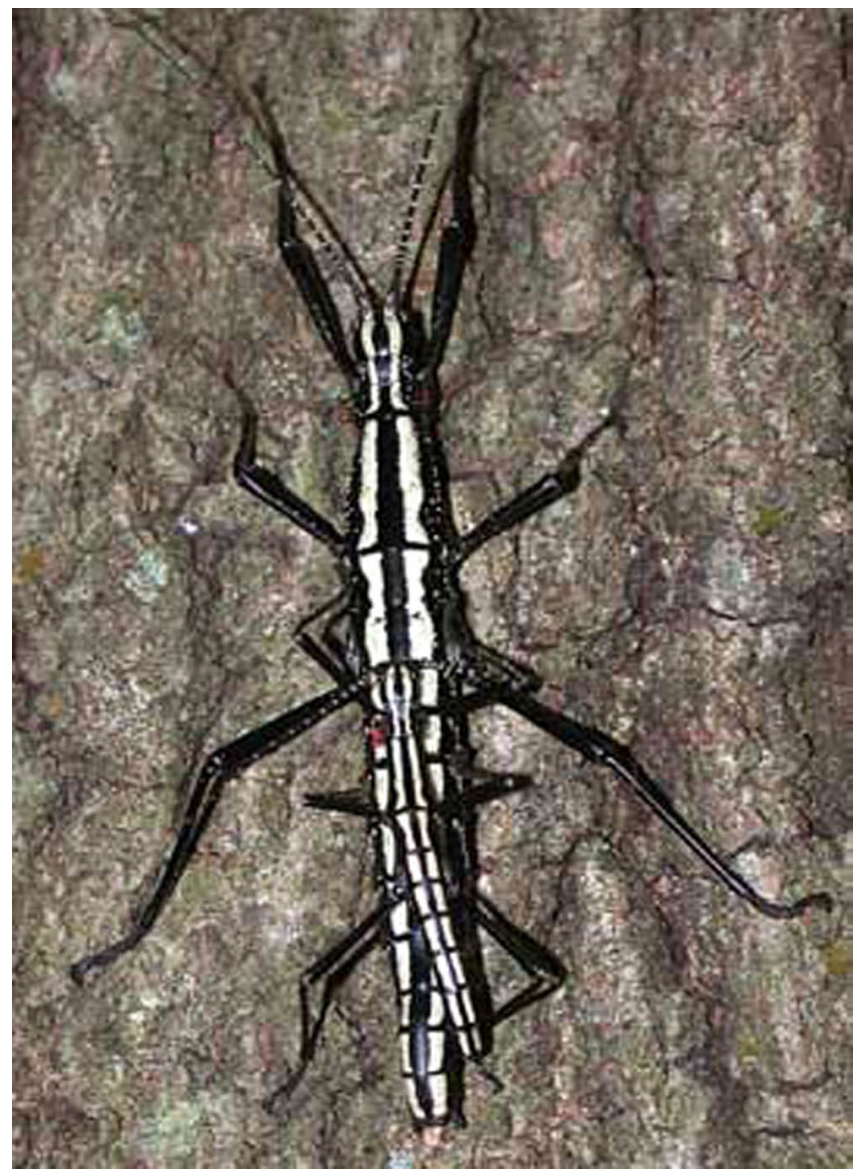

Figure 2. Male and female of the twostriped walkingstick, Anisomorpha buprestoides (Stoll), Ocala National Forest color form. Credits: Photograph by: Michael Thomas, FDOACS-DPI
Gnaphalium obtusifolium L." MacAtee (1918) reported a second hand report "...that Anisomorpha buprestoides discharges a vapor from the end of the abdomen and that the discharge is preceded by a peculiar crepidation..." He noted, correctly, that this report differs from almost all others.

Eisner (1965) reported, "The secretion is produced and stored in two elongate, sac-like glands situated in the thorax and opening just behind the head." Happ et al. (1966) presented detailed information on the structure of the glands. The glands open in notches at the anterolateral angles of the pronotum (Littig 1942). The glands are functional from birth and Eisner (1965) reported newly-hatched nymphs successfully repelling attacks by single ants. Meinwald et al. (1962) identified the active ingredient as a terpene dialdehyde related to catnip and named it anisomorphal.

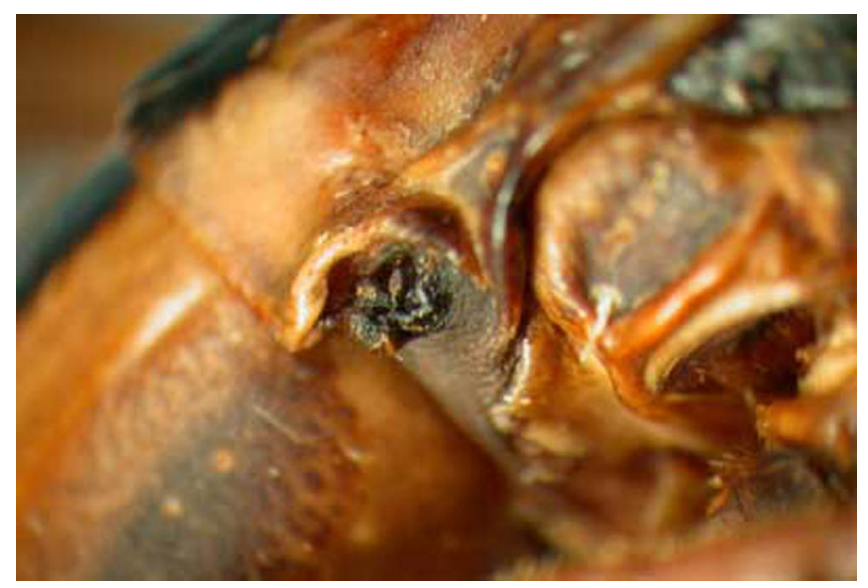

Figure 3. A side view of the twostriped walkingstick, Anisomorpha buprestoides (Stoll), showing the pronotal gland. Credits: Photograph by: Michael Thomas, FDOACS-DPI

Eisner (1965) reported that the stick insects generally discharged the secretion as a result of certain perceived threats. They can aim up to 30 to 40 cm with accuracy: "Anisomorpha discharges instantly in response to mild traumatic stimulation as, for example, when individual legs are pinched with forceps, or when the body is tapped or persistently prodded . . . Marksmanship is precise: the spray invariably drenches the particular instrument used for stimulation." Although most discharges required actual physical contact, Eisner (1965) found that the stick insects often would discharge at birds before being contacted by the bird. In trials, Eisner (1965) 
found the secretion to be an effective defense against ants, beetles, mice and birds; mouse- opossums (Marmosa sp.), however, managed to withstand the spray and consume the stick insect once its reservoir was depleted after up to five discharges from the larger females. One to two weeks are required to replenish the depleted reservoirs (Eisner 1965). Carlberg (1985) found that rats (Rattus norvegicus (Berkenhout)) initially were repelled, but some individuals managed to overcome the defense in subsequent attacks.

\section{Medical Importance}

Although Gray (1835) mentioned the defensive secretion of $A$. buprestoides, the first account of its effect on humans that could be located was by Stewart (1937), who wrote about an incident in Texas: "The victim was observing a pair of Anisomorpha buprestoides... with his face within two feet of the insects, when he received the discharge in his left eye. . The pain in his left eye was immediately excruciating; being reported to be as severe as if it had been caused by molten lead. Quick, thorough drenching with cool water allayed the burning agony to a dull aching pain. The pain eased considerably within the course of a few hours. Upon awakening the next morning the entire cornea was almost a brilliant scarlet in color and the eye was so sensitive to light and pressure for the next forty-eight hours that the patient was incapacitated for work. Vision was impaired for about five days." Symptoms gradually disappeared and there were no lasting effects. Albert (1947) described a similar but less severe incident.

Recent accounts (Dziedzyc 1992, Hatch et al. 1993, Paysse et al. 2001) report incidents with essentially similar symptoms, the first and most severe involving a dog. In that case, the dog suffered an ulcerated cornea, although the damage could have been self-inflicted after the encounter with the stick insect (Dziedzyc 1992). The recommended treatment includes immediate irrigation of the eye with large amounts of water, followed by administration of over-the-counter analgesics if needed for pain. Medical attention should be sought if more severe symptoms, such as decreased vision or light sensitivity, are present.

\section{Acknowledgments}

I thank Aaron Weed and Jeffrey White for supplying living specimens of the Ocala National Forest form of Anisomorpha buprestoides, Laura Torres-Miller of the West Virginia Department of Agriculture, for the loan of specimens, and Dr. Paul Skelley for help in setting up the photographs. Drs. Skelley and Lionel Stange criticized an earlier version of the manuscript.

\section{Selected References}

Albert RO. 1947. Another case of injury to the human eye by the walking stick, Anisomorpha (Phasmidae). Entomological News 58 : 57-59.

Blatchley WS. 1920. Orthoptera of northeastern America. Nature Publishing Co., Indianapolis. 784 p.

Bradley JC, Galil BS. 1977. The taxonomic arrangement of the Phasmatodea with keys to the subfamilies and tribes. Proceedings of the Entomological Society of Washington 79: 176-208.

Carlberg U. 1985. Chemical defence in Anisomorpha buprestoides (Houttuyn in Stoll') (Insecta: Phasmida). Zool. Anz. Jena 215: 177-188.

Caudell AN. 1903. The Phasmidae, or walkingsticks, of the United States. Proceedings of the U. S. National Museum 26: 863-885.

Davis WT. 1914. Notes on Orthoptera from the East Coast of Florida with descriptions of two new species of Belocephalus. Journal of the New York Entomological Society 22: 191-205.

Dziedzyc J. 1992. Insect defensive spray-induced keratitis in a dog. Journal of the American Veterinary Medicine Association 200: 1969.

Eisner T. 1965. Defensive spray of a phasmid insect. Science 148: 966-968.

Gray GR. 1835. Synopsis of the species of insects belonging to the family of Phasmidae. London. 48 p.

Gunning GE. 1987. Behavioral observations of the walking stick, Anisomorpha buprestoides 
(Phasmatodea: Phasmatidae). Florida Entomologist

70: 406-408.

Happ GM, Strandberg JD, Happ CM. 1966. The terpene-producing glands of a phasmid insect. Cell morphology and chemistry. Journal of Morphology 219: 143-160.

Hatch RL, Lamsens SD, Perchalski JE. 1993. Chemical conjunctivitis caused by spray of $A$. buprestoides. Two-striped walkingstick. Journal of the Florida Medical Association 80: 758-759.

Hetrick LA. 1949a. Field notes on a color variant of the two-striped walkingstick, Anisomorpha buprestoides, (Stoll). Florida Entomologist 32: 7477.

Hetrick LA. 1949b. The oviposition of the two-striped walkingstick, Anisomorpha buprestoides (Stoll). Proceedings of the Entomological Society of Washington 51: 103-104.

Littig KS. 1942. External anatomy of the Florida walking stick Anisomorpha buprestoides Stoll. Florida Entomologist 25: 33-41.

MacAtee WL. 1918. Vaporous discharge by Anisomorpha buprestoides (Orthoptera: Phasmidae). Entomological News 29: 388.

Meinwald J, Chadha MS, Hurst JJ, Eisner T. 1962. Defense methods of arthropods - IX.

Anisomorphal, the secretion of a phasmid insect. Tetrahedron Letters 1: 29-33.

Paysse EA, Holder S, Coats DK. 2001. Ocular injury from the venom of the southern walkingstick. Opthalmology 108: 190-191.

Rehn JA, Hebard M. 1916. Studies in the Dermaptera and Orthoptera of the Coastal Plain and Piedmont Region of the southeastern United States. Proceedings of the Academy of Natural Sciences of Philadelphia 1916: 87-214.

Stewart MA. 1937. Phasmid injury to the human eye. Canadian Entomologist 69: 84-86. 